\title{
PRZETWARZANIE DANYCH OSOBOWYCH PRZEZ GMINNE OŚRODKI POMOCY SPOŁECZNEJ W RAMACH PRZYZNAWANIA ŚWIADCZEŃ Z POMOCY SPOŁECZNEJ
}

\begin{abstract}
Abstrakt: Celem niniejszego opracowania jest analiza art. 100 ustawy o pomocy społecznej zmienionego ustawą wdrażającą RODO. Zakres tych rozważań obejmuje: określenie administratora danych; wskazanie kategorii przetwarzanych danych; realizację obowiązku informacyjnego wynikającego z art. 13 i 14 RODO; środki zabezpieczające przetwarzanie danych osobowych oraz obowiązek zachowania tajemnicy.
\end{abstract}

Słowa kluczowe: rozporządzenie 2016/679 (RODO), ustawa o pomocy społecznej, dane osobowe, przetwarzanie danych osobowych, gminny ośrodek pomocy społecznej

\section{WPROWADZENIE}

Zgodnie z art. 2 ust. 1 ustawy o pomocy społecznej (dalej: u.p.s.), wykonywanie zadań w zakresie pomocy społecznej — mające ,na celu umożliwienie osobom i rodzinom przezwyciężenie trudnych sytuacji życiowych, których nie są one w stanie pokonać, wykorzystując własne uprawnienia, zasoby i możliwości”" wiąże się z potrzebą przetwarzania danych osobowych przez gminne ośrodki pomocy społecznej (dalej: GOPS). Powody udzielania pomocy społecznej mogą być różne. Zalicza się do nich między innymi ubóstwo, bezrobocie, niepełnosprawność, długotrwałą lub ciężką chorobę, przemoc w rodzinie, potrzebę ochrony macierzyństwa lub wielodzietności, alkoholizm lub narkomanię ${ }^{2}$. Podstawą prawną przetwarzania danych osobowych przez GOPS-y jest art. 100 ust. 2 u.p.s. znowelizowany ustawą o zmianie niektórych ustaw $\mathrm{w}$ związku z zapewnieniem stosowania rozporządzenia Parlamentu Europejskiego i Rady (UE) 2016/679 z dnia

1 Ustawa z 12 marca 2004 roku o pomocy społecznej, tekst jedn. Dz.U. z 2020 r. poz. 1876 ze zm.

2 Zob. ibidem, art. 7. 
27 kwietnia 2016 roku w sprawie ochrony osób fizycznych w związku z przetwarzaniem danych osobowych i w sprawie swobodnego przepływu takich danych oraz uchylenia dyrektywy 95/46/WE (dalej także: ustawa wdrażająca RODO ${ }^{3}$ ). Artykuł ten stanowi, że ,podmioty i osoby realizujące zadania w zakresie pomocy społecznej określone w ustawie przetwarzają dane osobowe osób, do których stosuje się ustawę, oraz członków ich rodzin w zakresie i celu niezbędnym do realizacji zadań wynikających z ustawy". Należy jednak pamiętać, że w procesie tym musi zostać zachowany wymóg poufności. Zakazane jest zwłaszcza podawanie do publicznej wiadomości nazwisk osób korzystających z pomocy społecznej oraz rodzaju i zakresu przyznanego świadczenia ${ }^{4}$.

Celem niniejszego opracowania jest analiza treści art. 100 u.p.s. zmienionego ustawą wdrażającą RODO. Zakres tych rozważań obejmuje: określenie administratora danych; wskazanie kategorii przetwarzanych danych; realizację obowiąz$\mathrm{ku}$ informacyjnego wynikającego z art. 13 i 14 RODO; środki zabezpieczające przetwarzanie danych osobowych oraz obowiązek zachowania tajemnicy.

\section{GOPS JAKO ADMINISTRATOR DANYCH}

Problem z określeniem administratora danych w sektorze publicznym znany był już pod rządami ustawy o ochronie danych osobowych z 1997 roku $^{5}$ i pozostał aktualny wraz z rozpoczęciem stosowania rozporządzenia Parlamentu Europejskiego i Rady (UE) 2016/679 z 27 kwietnia 2016 roku w sprawie ochrony osób fizycznych w związku z przetwarzaniem danych osobowych i w sprawie swobodnego przepływu takich danych oraz uchylenia dyrektywy 95/46/WE (dalej RODO) ${ }^{6}$. Problemu należy upatrywać w kręgu podmiotów publicznych, którym można by potencjalnie nadać status administratora 7 . Jak wynika bowiem z art. 4 pkt 7 RODO, administrator oznacza osobę fizyczną lub prawną, organ publiczny, jednostkę lub

${ }^{3}$ Ustawa z 21 lutego 2019 roku o zmianie niektórych ustaw w związku z zapewnieniem stosowania rozporządzenia Parlamentu Europejskiego i Rady (UE) 2016/679 z dnia 27 kwietnia 2016 roku w sprawie ochrony osób fizycznych w związku z przetwarzaniem danych osobowych i w sprawie swobodnego przepływu takich danych oraz uchylenia dyrektywy 95/46/WE (ogólne rozporządzenie o ochronie danych), Dz.U. z 2019 r. poz. 730.

4 Art. 100 ust. 1 u.p.s.

5 Ustawa z 29 sierpnia 1997 roku o ochronie danych osobowych, Dz.U. z 1997 r. Nr 133, poz. 883 ze zm.

6 Rozporządzenie Parlamentu Europejskiego i Rady (UE) 2016/679 z dnia 27 kwietnia 2016 roku w sprawie ochrony osób fizycznych w związku z przetwarzaniem danych osobowych i w sprawie swobodnego przepływu takich danych oraz uchylenia dyrektywy 95/46/WE (ogólne rozporządzenie o ochronie danych), Dz.Urz. UE L 119/1 z 4 maja 2016 roku.

${ }^{7} \mathrm{~K}$. Witkowska-Nowakowska, Komentarz do art. 4, pkt 7, [w:] RODO Ogólne rozporządzenie o ochronie danych. Komentarz, red. E. Bielak-Jomaa, D. Lubasz, Warszawa 2018, s. 219. 
inny podmiot, który samodzielnie lub wspólnie z innymi ustala cele i sposoby przetwarzania danych osobowych; jeżeli cele i sposoby takiego przetwarzania są określone w prawie Unii lub w prawie państwa członkowskiego, to również w prawie Unii lub w prawie państwa członkowskiego może zostać wyznaczony administrator lub mogą zostać określone konkretne kryteria jego wyznaczenia.

Nie budzi więc wątpliwości, że jednoznaczne ustalenie statusu administratora może w praktyce okazać się dość skomplikowane. Niewykluczone przecież, że „w odniesieniu do tych samych zasobów i zaplecza logistycznego"8 będziemy mieli kilku administratorów. Na przykładzie starostwa możemy bowiem wskazać „zarząd jako administratora, osobno starostę, który w niektórych sprawach samodzielnie pozostaje organem właściwym w niektórych sprawach w oderwaniu od zarządu, radę powiatu, powiat jako całość - jako osoba prawna i starostwo jako pracodawcę" ". Wydaje się więc, że ,z punktu widzenia wszystkich podmiotów przetwarzających dane" 10 najlepszym rozwiązaniem problemu, jaki pojawia się w związku z prawidłowym zdefiniowaniem administratora byłoby określenie go wprost w regulacji ustawowej ${ }^{11}$ „bądź przynajmniej określenie kryteriów, które pozwoliłyby na przypisanie tej funkcji konkretnemu podmiotowi" ${ }^{\prime 2}$. Z tej pierwszej możliwości w odniesieniu między innymi do GOPS-ów skorzystał polski ustawodawca, który w art. 100 ust. 5 u.p.s. uznał je za administratorów danych osobowych przetwarzanych w celu przyznawania i udzielania świadczeń z pomocy społecznej.

8 https://www.prawo.pl/samorzad/prawo-dotyczace-administratorow-danych-osobowychjest,234730.html (dostęp: 31.10.2020).

9 Ibidem.

10 A. Kozłowska, Administrator w samorządzie terytorialnym, „Abi Expert” 2018, nr 3, s. 42.

11 Na tę kwestię zwraca uwagę M. Sakowska-Baryła: „Zapewne z możliwości ustawowego wskazania administratora ustawodawca polski będzie korzystać, działając także na podstawie przepisów RODO. Zważyć jednak należy, że w myśl art. 4 pkt 7 RODO takie »ustawowe« wyznaczenie administratora nie może być dowolne i nie może następować w każdych okolicznościach. Jak bowiem wynika z treści tego przepisu, w prawie Unii lub w prawie państwa członkowskiego może zostać wyznaczony administrator lub mogą zostać określone konkretne kryteria jego wyznaczania, jeżeli cele i sposoby przetwarzania są określone w prawie Unii lub w prawie państwa członkowskiego. Stąd też wyznaczenie administratora w przepisach prawa nie może się obyć bez określenia w przepisach celów i sposobów przetwarzania. Rozporządzenie nie precyzuje przy tym, czy określenie celów i sposobów oraz wskazanie administratora muszą następować w tym samym akcie, czy dopuszczalne jest rozłączne uregulowanie kwestii specyfiki przetwarzania danych, a więc jego celów i sposobów w jednym akcie, w innym zaś wskazanie administratora. Należy uznać, że dopuszczalne jest zarówno łączne uregulowanie wszystkich tych kwestii, jak i ujęcie ich w osobnych aktach. Analogicznie rzecz się ma w przypadku ustawowego określenia »konkretnych kryteriów wyznaczania« administratora"; eadem, Komentarz do art. 4 RODO, [w:] Ogólne rozporzadzenie o ochronie danych osobowych. Komentarz, Warszawa 2018, s. 98.

12 A. Kozłowska, op. cit., s. 42. Zob. na ten temat M. Jabłoński, K. Wygoda, Praktyczne znaczenie podstawowych pojęć RODO — wybrane zagadnienia, Wrocław 2019, s. $16 \mathrm{n}$. 


\section{KATEGORIE DANYCH OSOBOWYCH PRZETWARZANYCH PRZEZ GOPS-Y W SPRAWIE PRZYZNAWANIA ŚWIADCZEŃ Z POMOCY SPOŁECZNEJ}

Jak wynika z rozwiązań przyjętych w art. 4 pkt 1 RODO oraz ze sprostowania do RODO ${ }^{13}$, dane osobowe oznaczają wszelkie informacje o zidentyfikowanej lub możliwej do zidentyfikowania osobie fizycznej. Przy czym „możliwa do zidentyfikowania osoba fizyczna" to taka, którą można bezpośrednio lub pośrednio rozpoznać, w szczególności na podstawie identyfikatora takiego jak imię i nazwisko, numer identyfikacyjny (na przykład PESEL, numer dowodu osobistego), dane o lokalizacji (na przykład dane z GOPS-u), identyfikator internetowy (na przykład adres IP, nick) lub jeden bądź kilka szczególnych czynników określających fizyczną (na przykład siatkówka oka), fizjologiczną (na przykład grupa krwi), genetyczną (na przykład DNA), psychiczną, ekonomiczną (na przykład zaległości finansowe), kulturową lub społeczną (na przykład wyznanie, przynależność związkowa) tożsamość osoby fizycznej.

Oprócz powyższej definicji prawodawca unijny w art. 9 ust. 1 RODO odniósł się do szczególnych kategorii danych osobowych: ujawniających pochodzenie rasowe lub etniczne, poglądy polityczne, przekonania religijne lub światopoglądowe, przynależność do związków zawodowych oraz dane genetyczne ${ }^{14}$, dane biometryczne ${ }^{15}$, dane dotyczące zdrowia ${ }^{16}$, seksualności lub orientacji seksualnej. Poza tym katalogiem funkcjonują natomiast dane dotyczące wyroków skazujących oraz czynów zabronionych ${ }^{17}$, które dana osoba popełniła, a które można przetwarzać „wyłącznie pod nadzorem władz publicznych lub jeżeli przetwarza-

13 Sprostowanie do rozporządzenia Parlamentu Europejskiego i Rady (UE) 2016/679 z dnia 27 kwietnia 2016 roku w sprawie ochrony osób fizycznych w związku z przetwarzaniem danych osobowych i w sprawie swobodnego przepływu takich danych oraz uchylenia dyrektywy 95/46 (ogólne rozporządzenie o ochronie danych), Dz.Urz. UE L 127/2 z 23 maja 2018 roku, s. 4.

14 Art. 4 pkt 13 RODO stanowi: dane genetyczne „oznaczają dane osobowe dotyczące odziedziczonych lub nabytych cech genetycznych osoby fizycznej, które ujawniają niepowtarzalne informacje o fizjologii lub zdrowiu tej osoby i które wynikają w szczególności z analizy próbki biologicznej pochodzącej od tej osoby".

15 Według art. 4 pkt 14 RODO, dane biometryczne „oznaczają dane osobowe, które wynikają ze specjalnego przetwarzania technicznego, dotyczą cech fizycznych, fizjologicznych lub behawioralnych osoby fizycznej oraz umożliwiają lub potwierdzają jednoznaczną identyfikację tej osoby, takie jak wizerunek twarzy lub dane daktyloskopijne". Przy czym motyw 51 RODO wskazuje, że „przetwarzanie fotografii nie powinno zawsze stanowić przetwarzania szczególnych kategorii danych osobowych, gdyż fotografie są objęte definicją danych biometrycznych tylko w przypadkach, gdy są przetwarzane specjalnymi metodami technicznymi umożliwiającymi jednoznaczną identyfikację osoby fizycznej lub potwierdzenie jej tożsamości”.

${ }^{16} \mathrm{~W}$ myśl art. 4 pkt 15 RODO, dane dotyczące zdrowia „oznaczają dane osobowe o zdrowiu fizycznym lub psychicznym osoby fizycznej — w tym o korzystaniu z usług opieki zdrowotnej ujawniające informacje o stanie jej zdrowia".

17 Zob. Sprostowanie do rozporzadzenia Parlamentu Europejskiego i Rady (UE) 2016/679..., s. 4. 
nie jest dozwolone prawem Unii lub prawem państwa członkowskiego przewidującymi odpowiednie zabezpieczenia praw i wolności osób, których dane dotyczą. Wszelkie kompletne rejestry wyroków skazujących są prowadzone wyłącznie pod nadzorem władz publicznych"18.

Mając na względzie powyższe oraz przepisy u.p.s., nie może budzić wątpliwości, że przyznanie przez GOPS-y świadczeń z pomocy społecznej wiąże się z przetwarzaniem zarówno danych osobowych zwykłych — takich, które nie są danymi szczególnej kategorii (na przykład imię i nazwisko, adres zamieszkania, data urodzenia) - danych wrażliwych, jak i danych dotyczących wyroków skazujących i czynów zabronionych. Przyznanie tych świadczeń uzależnione jest w większości przypadków od przeprowadzenia rodzinnego wywiadu środowiskowego ${ }^{19}$, podczas którego pracownik socjalny przetwarza między innymi takie dane osobowe jak: imię i nazwisko, obywatelstwo, data urodzenia, adres zamieszkania, numer telefonu, seria i numer dokumentu potwierdzającego tożsamość, PESEL, stan cywilny, wysokość dochodu na osobę w rodzinie, miesięczne wydatki, dane dotyczące zdrowia ${ }^{20}$. Przetwarzane w powyższym celu dane pochodzą z różnych dokumentów, do których zalicza się na przykład dowód osobisty; skrócony odpis aktu urodzenia dziecka; decyzję właściwego organu w sprawie renty czy emerytury; orzeczenie lekarza orzecznika o niezdolności do pracy czy niezdolności do samodzielnej egzystencji; orzeczenie o niepełnosprawności albo orzeczenie o stopniu niepełnosprawności ${ }^{21}$. Dokonywanie różnego rodzaju czynności na wskazanych powyżej danych osobowych nie pozostaje więc bez wpływu na obowiązki ciążące na GOPS-ach oraz na uprawnienia przysługujące osobom, których dane dotyczą.

\section{OBOWIĄZEK INFORMACYJNY GOPS-U WZGLĘDEM OSOBY, KTÓREJ DANE DOTYCZĄ}

W procesie przetwarzania danych osobowych bardzo ważne jest, aby względem osoby, od której zbiera się dane, spełniony został obowiązek informacyjny nałożony na administratora $\mathrm{w}$ art. $13 \mathrm{RODO}^{22}$. Realizacja tego obowiązku ,naj-

18 Art. 10 RODO.

19 Przeprowadzenie rodzinnego wywiadu środowiskowego nie jest wymagane w przypadkach, o których mowa w art. 48a ust. 8; art. 48b ust. 5; art. 53a ust. 2 u.p.s.

20 Zob. załącznik nr 1 do rozporządzenia Ministra Rodziny, Pracy i Polityki Społecznej z 8 kwietnia 2021 roku w sprawie rodzinnego wywiadu środowiskowego, Dz.U. z 2021 r. poz. 893.

21 Art. 107 ust. 5b i 5d u.p.s.

22 Zob. na ten temat M. Gumularz, M. Kawecki, Prawo do poinformowania w przypadku zbierania danych od osoby, której dane dotycza, [w:] Realizacja praw osób, których dane dotycza, na podstawie RODO, red. B. Fischer, M. Sakowska-Baryła, Wrocław 2017, s. 93; A. Stec, Wybrane problemy obowiązu informacyjnego dotyczace samorządu terytorialnego $w$ kontekście RODO $i$ ustawy o ochronie danych osobowych, [w:] Prawo samorzadu terytorialnego - doświadczenia, wyzwania i perspektywy, Zielona Góra 2019, s. 391 n. 
częściej przyjmować będzie formę pisemnego przedłożenia podmiotowi danych kompletu informacji wynikających $\mathrm{z}$ tego przepisu, niezależenie od tego, w jaki sposób ta informacja będzie podmiotowi danych przekazywana. Informacje te mogą być zamieszczone $\mathrm{w}$ formularzu wypełnianym przez podmiot danych, w piśmie informacyjnym wręczanym do zapoznania się konkretnej osobie, wyświetlane na ekranie komputera czy urządzenia mobilnego najlepiej z koniecznością »odkliknięcia« właściwego okna celem potwierdzenia zapoznania się z nim"23. Klauzula informacyjna kierowana przez GOPS do osoby wnioskującej o świadczenia z pomocy społecznej musi więc zawierać: informacje o administratorze; dane kontaktowe inspektora ochrony danych; cele przetwarzania danych osobowych i podstawę prawną przetwarzania; określenie prawnie uzasadnionego interesu, jeżeli przetwarzanie odbywa się na podstawie art. 6 ust. 1 lit. f); informacje o odbiorcach danych osobowych lub kategoriach odbiorców, jeżeli takowi istnieją; informacje o zamiarze przekazania danych osobowych do państwa trzeciego lub organizacji międzynarodowej; okres przechowywania danych; informacje o prawach przysługujących osobie, której dane dotyczą; informacje o wymogu/dobrowolności podania danych osobowych; informacje o zautomatyzowanym podejmowaniu decyzji, w tym o profilowaniu.

Wymienione wyżej informacje muszą być sformułowane w zwięzłej, przejrzystej, zrozumiałej i łatwo dostępnej formie, jasnym i prostym językiem, co świadczy o konieczności zachowania przez administratora wymogu transparentności informacji względem osoby, której dane dotyczą. Poza tym jednorazowe spełnienie przez GOPS obowiązku informacyjnego względem osoby wnioskującej o dane świadczenie (na przykład zasiłek okresowy) zwalnia administratora (GOPS) z ponownego obowiązku informacyjnego, o ile wnioskodawca wystąpi o to samo świadczenie, a więc nie dojdzie do zmiany stanu faktycznego i prawnego.

Trzeba jednak mieć na uwadze, że odnośnie realizacji powyższego obowiązku informacyjnego w art. 100 ust. 3 u.p.s. wprowadzono pewne modyfikacje. Polegają one na zamieszczeniu informacji, o których mowa w art. 13 ust. 1 i 2 RODO, w widocznym miejscu budynku, gdzie udzielane są świadczenia w postaci interwencji kryzysowej, pracy socjalnej, poradnictwa, uczestnictwa w zajęciach klubu samopomocy, klubu samopomocy dla osób z zaburzeniami psychicznymi, schronienia $\mathrm{w}$ formie ogrzewalni i noclegowani, sprawienia pogrzebu, a także przyznania biletu kredytowanego oraz w celu świadczenia usług w ośrodkach wsparcia, rodzinnych domach pomocy, mieszkaniach chronionych i domach pomocy społecznej. Zakres przedmiotowy tego przepisu jest zatem szeroki i dotyczy obowiązku informacyjnego przy udzielaniu świadczeń niewymagających wydania decyzji administracyjnej oraz świadczenia usług w jednostkach organizacyjnych

23 M. Sakowska-Baryła, Komentarz do art. 13 RODO, [w:] Ogólne rozporządzenie o ochronie danych osobowych. Komentarz, Warszawa 2018, s. 211. 
pomocy społecznej24, co oznacza, że ma on zastosowanie także do GOPS-ów. Administrator musi jednak pamiętać, aby poinformować osobę, której dane dotyczą, o lokalizacji klauzuli informacyjnej najpóźniej przy pierwszej czynności skierowanej do tej osoby ${ }^{25}$. Może to nastąpić choćby poprzez ustne lub pisemne przekazanie osobie, której dane dotyczą, informacji o umiejscowieniu klauzuli informacyjnej.

$\mathrm{W}$ postępowaniu $\mathrm{w}$ sprawie przyznania świadczenia $\mathrm{z}$ pomocy społecznej należy pamiętać, że GOPS przetwarza dane nie tylko osoby wnioskującej, ale także dane członków rodziny przekazane przez nią na etapie składania wniosku o przyznanie pomocy społecznej lub podczas rodzinnego wywiadu środowiskowego. Czy w takiej sytuacji na GOPS-ie ciąży obowiązek informacyjny z art. 14 ust. 1 i 2 RODO? W mojej ocenie nie, ponieważ administrator (GOPS) będzie mógł powołać się na art. 14 ust. 5 lit. c) RODO, który przewiduje wyłączenie tego obowiązku. Zgodnie z tym przepisem, obowiązek informacyjny $\mathrm{z}$ art. 14 nie ma zastosowania, ,gdy - i w zakresie, w jakim: pozyskiwanie lub ujawnienie jest wyraźnie uregulowane prawem Unii lub prawem państwa członkowskiego, któremu podlega administrator, przewidującym odpowiednie środki chroniące prawnie uzasadnione interesy osoby, której dane dotyczą". Należy zatem mieć na względzie, że pozyskiwanie przez GOPS-y danych osobowych w celu przyznania świadczeń z pomocy społecznej uregulowane jest w prawie państwa członkowskiego, to jest w ustawie o pomocy społecznej. Przyznanie lub odmowa takiego świadczenia następuje w drodze decyzji administracyjnej po uprzednim przeprowadzeniu rodzinnego wywiadu środowiskowego ${ }^{26}$. Sposób pozyskiwania przez GOPS danych osobowych, a także katalog tych danych określony został w rozporządzeniu Ministra Rodziny, Pracy i Polityki Społecznej w sprawie rodzinnego wywiadu środowiskowego ${ }^{27}$. Ponadto warto wspomnieć, że z uwagi na trwającą pandemię COVID-19 wprowadzono pewne modyfikacje odnośnie do realizacji rodzinnego wywiadu środowiskowego. Zostały one ujęte w treści art. 15o ustawy o szczególnych rozwiązaniach związanych z zapobiegniem, przeciwdziałaniem i zwalczaniem COVID-19, innych chorób zakaźnych oraz wywołanych nimi sytuacji kryzysowych. Mianowicie, jeżeli wymagane jest przeprowadzenie rodzinnego wywiadu środowiskowego lub jego aktualizacja, w szczególności z osobą lub rodziną, które zostały poddane kwarantannie w związku z podejrzeniem zakażenia lub choroby zakaźnej, ustalenie sytuacji osobistej, rodzinnej, dochodowej i mająt-

24 A. Lisowski, M. Sarna, Komentarz do art. 100, [w:] R. Górna et al., Ustawa o pomocy społecznej. Komentarz, Warszawa 2019, s. 313.

25 Zob. art. 100 ust. 4 u.p.s.

26 Wydanie decyzji administracyjnej o odmowie przyznania biletu kredytowanego oraz decyzji w sprawach cudzoziemców, o których mowa w art. 5a, nie wymaga przeprowadzenia rodzinnego wywiadu środowiskowego - art. 106, ust. 4 u.p.s. Zob. także art. 48b ust. 2; art. 53a ust. 2 u.p.s.

27 Rozporządzenie Ministra Rodziny, Pracy i Polityki Społecznej z 8 kwietnia 2021 roku w sprawie rodzinnego wywiadu środowiskowego, Dz.U. z 2021 r. poz. 893. 
kowej zamiast przeprowadzenia rodzinnego wywiadu środowiskowego lub jego aktualizacji może nastąpić na podstawie:

1. rozmowy telefonicznej przeprowadzonej przez pracownika socjalnego, a w przypadku osób niepełnosprawnych z powodu dysfunkcji narządu słuchu przy wykorzystaniu środków wspierających komunikowanie się oraz

2. dokumentów lub oświadczenia, o którym mowa w art. 107 ust. 5b u.p.s., a także ich kopii, w tym elektronicznych, uzyskanych od osoby lub rodziny ubiegającej się o pomoc, lub

3. informacji udostępnionych przez podmioty, o których mowa w art. 105 u.p.s. ${ }^{28}$

Przetwarzanie danych osobowych wnioskodawcy i członków jego rodziny w związku ze sprawą przyznania świadczenia z pomocy społecznej jest niezbędne do wypełnienia obowiązku prawnego, jaki ciąży na administratorze ${ }^{29}$, czyli GOPS-ie. Sposób pozyskiwania tych danych określony został we wskazanych wyżej aktach prawa powszechnie obowiązującego. Wobec tego można uznać, że pozyskiwanie od osoby wnioskującej danych członków jej rodziny, które są konieczne do wydania decyzji o przyznaniu lub odmowie przyznania świadczenia z pomocy społecznej, uprawnia GOPS do odstąpienia od spełnienia wobec członków rodziny wnioskodawcy obowiązku informacyjnego, o którym mowa w art. $14 \mathrm{RODO}^{30}$.

\section{4. ŚRODKI ZABEZPIECZAJĄCE PRZETWARZANIE DANYCH OSOBOWYCH PRZEZ GOPS-Y W SPRAWIE PRZYZNAWANIA ŚWIADCZEŃ Z POMOCY SPOŁECZNEJ}

Zmiany, które wprowadzono ustawą wdrożeniową RODO w art. 100 u.p.s., nie sprowadzają się tylko do wskazanych wyżej obszarów. Swoim zakresem obejmują także zabezpieczenia stosowane przez administratora w celu ochrony danych osobowych, które polegają co najmniej na:

1. dopuszczeniu do przetwarzania danych osobowych wyłącznie osób posiadających pisemne upoważnienie wydane przez administratora danych;

2. pisemnym zobowiązaniu osób upoważnionych do przetwarzania danych osobowych do zachowania ich w tajemnicy ${ }^{31}$.

Zastosowanie wskazanych wyżej środków ma charakter uprzedni. Administrator (GOPS) przed dopuszczeniem na przykład praktykanta lub stażysty do

28 Art. 15o ustawy z 2 marca 2020 roku o szczególnych rozwiązaniach związanych z zapobiegniem, przeciwdziałaniem i zwalczaniem COVID-19, innych chorób zakaźnych oraz wywołanych nimi sytuacji kryzysowych, Dz.U. z 2020 r. poz. 374 ze zm.

${ }_{29}$ Zob. art. 6, ust. 1, lit. c) RODO.

30 Por. https://uodo.gov.pl/pl/138/1543 (dostęp: 31.10.2020).

31 Art. 100 ust. 6 u.p.s. 
przetwarzania danych musi przygotować upoważnienie oraz odebrać zobowiązanie do zachowania przezeń tajemnicy. Upoważnienie, o którym mowa, powinno określać zakres danych osobowych oraz rodzaje operacji na danych, które mogą być dokonywane przez osoby dopuszczone, aby nie doszło do nadmiernego przetwarzania danych osobowych ${ }^{32}$.

Powyższe środki - mające na celu zapobiec niezgodnemu z prawem dostępowi do danych osoby (danych członków jej rodziny) ubiegającej się o świadczenie z pomocy społecznej lub korzystającej z przyznanych świadczeń, a także niezgodnemu z prawem ich wykorzystaniu - mimo że stanowią dobre rozwiązanie, to wskazują jednak tylko pewne minimum, które administrator musi wypełnić, o czym świadczy użyte w art. 100 ust. 6 u.p.s. sformułowanie „,co najmniej”. Administrator nie powinien więc ograniczać się do minimalnych wymogów, lecz podjąć działania w celu ustalenia, czy w jego przypadku wskazane byłoby zastosowanie także i innych środków ochrony — takich, które będą odpowiednie do zagrożeń i ryzyka związanego z przetwarzaniem danych osobowych na potrzeby przyznawania świadczeń z pomocy społecznej - mając na uwadze sposób ich przetwarzania, to jest całkowicie lub częściowo zautomatyzowany czy też w sposób inny niż zautomatyzowany. Mogą to być choćby „narzędzia organizacyjne (procedury), narzędzia fizyczne (na przykład klucze, bezpieczne koperty, kontrola dostępu), informatyczne (przykładowo poziomy uprawnień, firewalle, podziały dostępu, systemy wykrywania włamań, narzędzia antywirusowe, usługi cyberbezpieczeństwa real time - chmurowe)"33. W trakcie wyboru zabezpieczeń ważne jest, aby administrator wziął pod uwagę stan wiedzy technicznej, koszt wdrożenia oraz charakter, zakres, kontekst i cele przetwarzania oraz ryzyko naruszenia praw lub wolności osób fizycznych o różnym prawdopodobieństwie wystąpienia i wadze ${ }^{34}$. Jak widzimy, dobór odpowiednich środków ochrony zależy od uprzednio przeprowadzonej analizy ryzyka związanego z przetwarzaniem danych ${ }^{35}$. Przy czym ,ryzyko należy oszacować na podstawie obiektywnej oceny, w ramach której stwierdza się, czy z operacjami przetwarzania danych wiąże się ryzyko lub wysokie ryzyko"36. W razie gdy wystąpi to ostatnie administrator zobowiązany jest do przeprowadzenia oceny skutków dla ochrony danych, o której mowa w art. 35 RODO.

Mając powyższe na względzie, należy podkreślić, że ograniczenie się administratora do środków ochrony wskazanych w art. 100 ust. 6 u.p.s. może okazać

32 Art. 5 ust. 1 lit. c) RODO: „Dane osobowe muszą być: c) adekwatne, stosowne oraz ograniczone do tego, co niezbędne do celów, w których są przetwarzane (»minimalizacja danych «)".

33 A.P. Czarnowski, M. Gawroński, Bezpieczeństwo, [w:] Ochrona danych osobowych. Przewodnik po ustawie i RODO z wzorami, red. M. Gawroński, Warszawa 2018, s. 320.

34 Art. 32 ust. 1 RODO.

35 Zob. na ten temat M. Jabłoński, J. Węgrzyn, Zmiana modelu ochrony danych osobowych - podejście oparte na ryzyku, privacy by design $i$ privacy by default, [w:] Reforma ochrony danych osobowych a jawność dostępu do informacji sądowej - aspekty proceduralne, red. M. Jabłoński, K. Flaga-Gieruszyńska, K. Wygoda, Wrocław 2017, s. 75 n.

36 Motyw 76 zd. 2 RODO. 
się niewystarczające. Administrator powinien więc zweryfikować, czy przyjęcie minimalnych zabezpieczeń $\mathrm{w}$ jego przypadku będzie skuteczne, to jednak wymaga podjęcia przez niego wskazanych wyżej działań. Działania te są jak najbardziej zasadne, ponieważ w razie kontroli Prezesa Urzędu Ochrony Danych Osobowych administrator będzie mógł wykazać, że w wyniku przeprowadzonej analizy ryzyka konieczne lub nie było wdrożenie środków ochrony innych niż wskazane w art. 100 ust. 6 u.p.s. $Z$ uwagi na szybki postęp techniczny przyjęte środki muszą być poddawane przeglądom i w razie potrzeby uaktualniane, aby zapobiec ewentualnym zagrożeniom, które pojawiają się przy przetwarzaniu całkowicie lub częściowo zautomatyzowanym.

\section{OBOWIĄZEK ZACHOWANIA W TAJEMNICY INFORMACJI UZYSKANYCH W ZWIĄZKU Z WYKONYWANIEM ZADAŃ Z ZAKRESU POMOCY SPOŁECZNEJ}

Zapewnienie właściwej ochrony informacjom wykorzystywanym w postępowaniu w sprawie świadczeń z pomocy społecznej, to proces, na który składa się wiele elementów. Jednym z nich jest obowiązek zachowania tajemnicy, który wyrażony został w art. 100 ust. 7 u.p.s.: „Podmioty i osoby realizujące zadania w zakresie pomocy społecznej określone w niniejszej ustawie obowiązane są do zachowania w tajemnicy wszelkich informacji i danych, które uzyskały przy wykonywaniu tych zadań". Jak wynika z treści zacytowanego przepisu, jego zakres podmiotowy i przedmiotowy jest szeroki. Ten pierwszy obejmuje podmioty i osoby realizujące zadania w zakresie pomocy społecznej. Natomiast drugi tyczy się nie tylko danych osobowych, ale i wszelkich informacji pozyskanych w ramach realizacji zadań pomocy społecznej. Zalicza się do nich informacje o przeżyciach danej osoby, informacje o jej sąsiadach, dalszych krewnych itp.

Nie budzi zatem wątpliwości, że do kategorii osób realizujących zadania z zakresu pomocy społecznej w GOPS-ie zalicza się na przykład referenta ds. realizacji świadczeń z pomocy społecznej czy też pracownika socjalnego. W przypadku tego ostatniego nie będzie miał zastosowania art. 100 ust. 7 u.p.s., bowiem kwestia tajemnicy pracownika socjalnego została podniesiona do rangi obowiązku ustawowego ${ }^{37}$ ujętego $\mathrm{w}$ art. 119 ust. 2 pkt 5 u.p.s. W myśl tego przepisu, pracownik socjalny przy wykonywaniu zadań jest obowiązany zachować w tajemnicy ${ }^{38}$ informacje uzyskane w toku czynności zawodowych, także po ustaniu zatrudnienia, chyba że działa to przeciwko dobru osoby lub rodziny.

37 K. Roszewska, Tajemnica pracownika socjalnego, , Monitor Prawniczy” 2014, nr 23, s. 1271.

38 Mowa tu o tajemnicy zawodowej. Zob. na ten temat M. Jabłoński, J. Węgrzyn, Ochrona tajemnic osób wykonujacych prawnicze zawody zaufania publicznego, Wrocław 2018, s. $91 \mathrm{n}$. 
Jak wynika z rozwiązań przyjętych na gruncie art. 119 ust. 2 pkt 5 u.p.s., zakres przedmiotowy tajemnicy zawodowej pracownika socjalnego nie ogranicza się do informacji pozyskanych w postępowaniu w sprawie świadczeń z pomocy społecznej. Dotyczy on także informacji uzyskanych w ramach wykonywania innych czynności zawodowych. Tajemnicą, o której mowa, objęte są więc informacje uzyskane „,bezpośrednio od osób korzystających z pomocy społecznej, jak i zwierzchników, współpracowników, bądź innych instytucji”"39. Zalicza się do nich na przykład informacje o sytuacji osobistej, rodzinnej, dochodowej i majątkowej wnioskodawcy, informacje o przyznanych świadczeniach, jak również informacje, które nie były konieczne w postępowaniu o przyznanie świadczenia — jak choćby informacja o stanie zdrowia sąsiadki — ale o których pracownik socjalny dowiedział się w toku wykonywanych czynności zawodowych ${ }^{40}$.

Poza szeroko określonym zakresem informacji objętych tajemnicą zawodową pracownika socjalnego, ustawodawca podkreślił, że obowiązek zachowania tajemnicy trwa także po ustaniu zatrudnienia. Nie ma on jednak charakteru absolutnego, ponieważ pracownik socjalny może od niego odstąpić, gdy pozostawienie informacji w tajemnicy działałoby przeciwko dobru osoby lub rodziny. $\mathrm{Z}$ sytuacją taką mielibyśmy do czynienia w przypadku stwierdzenia przemocy w rodzinie. Ustawodawca nie pozostawił takiej swobody innym (niż pracownik socjalny) osobom realizującym zadania z zakresu pomocy społecznej, co wynika z wykonywanych przez nie zadań. Poza tym warto zwrócić uwagę na jeszcze jedną kwestię, a mianowicie prawo do odmowy składania zeznań w postępowaniu cywilnym i karnym z uwagi na obowiązek zachowania tajemnicy. W tym pierwszym podstawą prawną jest art. $261 \S 2$ Kodeksu postępowania cywilnego ${ }^{41}$, który upoważnia świadka - w tym przypadku pracownika socjalnego — do odmowy odpowiedzi na zadane mu pytanie, jeżeli zeznanie miałoby być połączone z pogwałceniem istotnej tajemnicy zawodowej. Przyjęcie takiego rozwiązania oznacza, że ,ani strony, ani organ procesowy nie mogą zwolnić świadka z zachowania tajemnicy zawodowej" ${ }^{\prime 2}$. W tym drugim — podstawą prawną jest art. $180 \S 1$ k.p.k. ${ }^{43}$, który ma zastosowanie już nie tylko do pracownika socjalnego, ale także i innej osoby realizującej zadania w zakresie pomocy społecznej. W przepisie tym wyraźnie bowiem wskazano, że osoby obligowane do zachowania tajemnicy związanej z wykonywaniem zawodu lub funkcji mogą odmówić zeznań co do okoliczności, na które rozciąga się ten obowiązek, chyba że sąd lub prokurator

39 K. Roszewska, op. cit., s. 1271.

40 Ibidem.

41 Ustawa z 17 listopada 1964 roku - Kodeks postępowania cywilnego, tekst jedn. Dz.U. z 2021 r. poz. 2052 ze zm.

42 E. Marszałkowska-Krześ, Komentarz do art. 261, [w:] Kodeks postępowania cywilnego. Komentarz, red. E. Marszałkowska-Krześ, Warszawa 2020.

43 Ustawa z 6 czerwca 1997 roku — Kodeks postępowania karnego, tekst jedn. Dz.U. z 2021 r. poz. 534 . 
dla dobra wymiaru sprawiedliwości zwolni te osoby od obowiązku zachowania tajemnicy, jeżeli ustawy szczególne nie stanowią inaczej. Na postanowienie w tym przedmiocie przysługuje zażalenie.

\section{PODSUMOWANIE}

Dostosowanie polskiego porządku prawnego do wymogów przewidzianych w RODO wiązało się z potrzebą podjęcia działań w sferze legislacyjnej. Ich efektem jest nie tylko nowa ustawa o ochronie danych osobowych ${ }^{44}$, ale także wprowadzone ustawą wdrażającą RODO zmiany w wielu ustawach, między innymi w ustawie o pomocy społecznej. Odnosząc się do zmian, o których mowa w art. 100 u.p.s. dostrzeżemy, że sprowadzają się one do:

— określenia administratora, co jest niezmiernie ważne $\mathrm{z}$ uwagi na pojawiające się w tym obszarze problemy;

- nadania podmiotom i osobom realizującym zadania w zakresie pomocy społecznej ustawowego upoważnienia do przetwarzania danych osób, do których stosuje się u.p.s oraz członków ich rodzin w zakresie i celu niezbędnym do realizacji zadań wynikających z tej ustawy;

- ograniczenia obowiązku informacyjnego, o którym mowa w art. 13 ust. 1 i 2 RODO w zakresie wskazanym w u.p.s., co wydaje się być dobrym rozwiązaniem, ponieważ z jednej strony ułatwia administratorowi realizację nałożonego na niego obowiązku, a z drugiej — nie pozbawia podmiotu danych możliwości zapoznania się z klauzulą informacyjną zamieszczoną w odpowiednim miejscu ${ }^{45}$;

- wskazania minimalnych wymogów w zakresie zabezpieczenia danych osobowych, co nie zwalnia administratora (GOPS) z obowiązku przeprowadzenia analizy ryzyka związanego z przetwarzaniem danych. Dopiero na podstawie wyniku dokonanej analizy administrator będzie mógł podjąć decyzję, jakie środki techniczne i organizacyjne będą odpowiednie do zagrożeń i ryzyka związanego z przetwarzaniem danych $w$ ramach przyznawania świadczeń z pomocy społecznej;

- nałożenia na podmioty i osoby realizujące zadania w zakresie pomocy społecznej obowiązku zachowania w tajemnicy wszelkich informacji i danych, które uzyskały przy wykonywaniu tych zadań.

Sumując, można uznać, że zmiany przyjęte w art. 100 u.p.s. stanowią dobre rozwiązanie. Określają one zasady przetwarzania danych osobowych w postępowaniu w sprawie przyznawania świadczeń z pomocy społecznej dzięki którym administratorzy — w tym przypadku GOPS-y — wiedzą, jakie czynności podjąć, aby w sposób prawidłowy wywiązać się z nałożonych na nich obowiązków.

44 Ustawa z 10 maja 2018 roku o ochronie danych osobowych, tekst jedn. Dz.U. z 2019 r. poz. 1781 .

$45 \mathrm{~W}$ tym miejscu warto wspomnieć, że przyjęcie takiego rozwiązania umożliwia art. 23 ust. 1 lit. e) RODO. 


\section{PRINCIPLES OF PERSONAL DATA PROCESSING BY COMMUNAL SOCIAL WELFARE CENTRES WITHIN THE FRAMEWORK OF SOCIAL WELFARE BENEFITS PROVIDED}

\section{Summary}

The purpose of this study is to analyze art. 100 of the Act on Social Assistance as amended by the Act implementing the GDPR. The scope of these considerations includes: identification of the data controller; indication of the categories of data processed; implementation of the information obligation resulting from Article 13 and Article 14 GDPR; measures securing the processing of personal data and the duty of confidentiality.

Keywords: Regulation 2016/679 (GDPR), Act on Social Assistance, personal data, processing personal data, communal social welfare center

\section{BIBLIOGRAFIA}

Czarnowski A.P., Gawroński M., Bezpieczeństwo, [w:] Ochrona danych osobowych. Przewodnik po ustawie i RODO z wzorami, red. M. Gawroński, Warszawa 2018.

Gumularz M., Kawecki M., Prawo do poinformowania w przypadku zbierania danych od osoby, której dane dotycza, [w:] Realizacja praw osób, których dane dotycza, na podstawie RODO, red. B. Fischer, M. Sakowska-Baryła, Wrocław 2017.

Jabłoński M., Węgrzyn J., Zmiana modelu ochrony danych osobowych — podejście oparte na ry$z y k u$, privacy by design $i$ privacy by default, [w:] Reforma ochrony danych osobowych a jawność dostępu do informacji sadowej - aspekty proceduralne, red. M. Jabłoński, K. Flaga-Gieruszyńska, K. Wygoda, Wrocław 2017.

Jabłoński M., Węgrzyn J., Ochrona tajemnic osób wykonujących prawnicze zawody zaufania publicznego, Wrocław 2018.

Jabłoński M., Wygoda K., Praktyczne znaczenie podstawowych pojęć RODO - wybrane zagadnienia, Wrocław 2019.

Kozłowska A., Administrator w samorządzie terytorialnym, „Abi Expert” 2018, $\mathrm{nr} 3$.

Lisowski A., Sarna M., Komentarz do art. 100, [w:] R. Górna et al., Ustawa o pomocy społecznej. Komentarz, Warszawa 2019.

Marszałkowska-Krześ E., Komentarz do art. 261, [w:] Kodeks postępowania cywilnego. Komentarz, red. E. Marszałkowska-Krześ, Warszawa 2020.

Roszewska K., Tajemnica pracownika socjalnego, ,, Monitor Prawniczy” 2014, nr 23.

Sakowska-Baryła M., Komentarz do art. 4 RODO, [w:] Ogólne rozporzadzenie o ochronie danych osobowych. Komentarz, red. M. Sakowska-Baryła, Warszawa 2018.

Sakowska-Baryła M., Komentarz do art. 13 RODO, [w:] Ogólne rozporządzenie o ochronie danych osobowych. Komentarz, red. M. Sakowska-Baryła, Warszawa 2018.

Stec A., Wybrane problemy obowiazku informacyjnego dotyczace samorzadu terytorialnego $w$ kontekście RODO i ustawy o ochronie danych osobowych, [w:] Prawo samorzadu terytorialnego - doświadczenia, wyzwania i perspektywy, red. A. Bisztyga, A. Chodorowska, A. Feja-Paszkiewicz, Zielona Góra 2019.

Witkowska-Nowakowska K., Komentarz do art. 4 pkt 7, [w:] RODO. Ogólne rozporzadzenie o ochronie danych. Komentarz, red. E. Bielak-Jomaa, D. Lubasz, Warszawa 2018. 